\title{
Control over one's environment? Leveling political capabilities to advance procedural justice in Flood Risk Management
}

\author{
Lieke Brackel $^{1}$, Udo Pesch ${ }^{1}$ and Neelke Doorn ${ }^{1}$ \\ ${ }^{1}$ Delft University of Technology, Faculty of Policy, Technology \& Management, Jaffalaan 52628 BX Delft
}

\begin{abstract}
Land use change, managed retreat, and relocation programs are examples of exposure reduction measures in Flood Risk Management (FRM). Procedural justice research can help to address inequalities in people's ability to shape FRM decision-making. Relevant, as ample controversies related to exposure reduction have been documented. In this paper, the concept of political capabilities developed by Holland and Nussbaum is proposed to help better understand and potentially resolve inequalities in FRM decision-making. We propose to understand political capabilities as having sufficient political control over one's environment. In this way, the analysis can include both actors that have too little as well as those that have too much political influence. This paper further discusses the possibilities and limitations of the concept of political capabilities for FRM. The concept of political capabilities draws attention to the initial stages of FRM politics and is adaptable to different decision-making contexts. Moreover, political capabilities shift the focus from vulnerability to human agency, which also helps to address concerns in the literature about involuntary relocations and the loss of autonomy. The Dutch Room for the River program is proposed as an empirical case to test and develop the political capabilities framework for European Flood Risk Management.
\end{abstract}

\section{Exposure reduction in FRM}

Uncertainties about the exact nature of climate impacts make it difficult to determine whether continuation of current land use practices and protection levels are feasible and desirable (Haasnoot et al. 2020; Klijn et al. 2016; Maier et al. 2016). The Intergovernmental Panel on Climate Change risk framework discusses climate risk as a function of three elements: hazard, vulnerability, and exposure (IPCC 2014). Exposure of communities to flood hazards should be understood in geographical terms, for instance, measures aiming to reduce the exposure of inhabitants and infrastructure to flood hazards are land use change and relocation. Examples of contested exposure reducing policy measures are buy out programs, no-build zones in flood plains, coastal realignment in the name of nature restoration, and managed retreat. Managed retreat is a form of state-led relocation, and in this respect differs from autonomous human migration/resettlement (Ajibade, Sullivan, and Haeffner 2020). Exposure reduction measures are prone to conflicts due to cultural, emotional, and financial attachments of inhabitants to current practices (Adams 2016), uncertainties about the impacts of natural hazards (Haasnoot et al. 2020; Klijn et al. 2016), and conflicting sociotechnical imaginaries about the best type of land use for an area (Bijker 2002; Boelens et al. 2016; Jasanoff and Kim 2019; Morita 2016).
Due to climate change, we can anticipate more conflicts about exposure reducing measures between topdown governing institutions and local populations having to relocate or change their way of living to avoid climate impacts. Moreover, existing inequalities may be reinforced (Heyward 2017; Schlosberg 2007, 2012). Vulnerability to natural hazards is unequally distributed between different geographic locations, most notably between the Global North and Global South, but also within communities (Adger et al. 2006; Eriksen, Nightingale, and Eakin 2015; O'Brien et al. 2007; Schlosberg, Collins, and Niemeyer 2017). Procedural justice theories deal with inequality in political decisionmaking and the justness of institutions (Holland 2017; Young 1999). Including procedural justice is relevant because inequalities can be reproduced when disadvantaged members of a community have less influence on decision-making processes.

This study investigates how to advance procedural justice of exposure reduction measures in climate adaptation and flood risk management. We will not defend one of the existing substantive principles of distributive justice, such as egalitarianism or utilitarianism, or develop new substantive principles to effectuate just FRM measures. Instead, we will focus on improving the procedural justness of the decision-making process between these competing justice principles and values in FRM. In part, because the background

\footnotetext{
a Corresponding author: a.k.c.brackel@tudelft.nl

DOI 10.3311/FLOODRisk2020.22.4
} 
assumption of value pluralism tells us that multiple and possibly competing values can be equally defendable (Doorn 2019). Second, there is a pragmatic argument, defended by Holland (2017): even if an ultimate hierarchy of substantive values in FRM may be defendable in theory, this still does not resolve the pluralism we encounter in practice. People have different views, and there will always be disagreement between actors about which values should be given priority in FRM. We depart from the assumption that (latent) conflict is an inherent part of water management. Procedural justice theories can help to design fairer decision-making processes, for example by mitigating the extent to which current inequalities influence decisionmaking outcomes.

The structure of this conference paper is as follows: In the next section, the results are presented of the exploratory literature review about justice, exposure reduction measures, and FRM. It is argued that the value of autonomy is not included explicitly enough in existing governance frameworks. Moreover, too often authors focus on instrumental participation, the mere implementation of government decisions, and the right to appeal in the aftermath of such a decision. Yet, we argue that the decision-making phase before measures are implemented is critical to understand procedural justice and the possible reproduction of inequalities.

To overcome this problem, we will propose the concept of political capabilities developed by Holland and Nussbaum in section three. By introducing this concept our attention is directed towards the value of autonomy and political influence in the starting phase of a project. In section four, first steps are made to examine the relevance of political capabilities as an analytic concept for the Dutch Room for the River program. Studying already implemented FRM measures and past controversies, can provide an empirical basis to better understand procedural justice and to be expected climate adaptation controversies in Western-European contexts. .

\section{Competing justice claims and procedural justice in FRM}

Fierce conflicts can be anticipated if flood risk policies aim to change land use practices or relocate citizens. Ample examples of such controversies exist in the literature (Baker et al. 2018; Begg 2018; Lynn 2017; Otto, Hornberg, and Thieken 2018). An exploratory literature review was conducted to learn how principles of justice and controversies are currently discussed in FRM literature. The results of this literature review show a mixture of different and sometimes competing values that are relevant in flood risk management. For example: safety from flooding, economic development and resource efficiency, landscape and nature protection, attachment to place, social justice, and adaptive capacity or resilience. Similarly, a variety of lists of normative principles for 'good government conduct' were encountered, especially covering dilemmas with relocations. The systematic literature review by Tadgell et al. (2018) provides a synthesis of principles for good conduct in state-led relocation in lower-income countries: proactivity (before a crisis takes place), participation and communication, permanence (new sites habitable for the long-term), adequate compensation, and livelihood protection. Alexander et al. [2016] present a description of elements attributing to the legitimacy of FRM governance arrangements, namely: social equity, accountability, transparency, participation, access to information, procedural justice, and acceptability. Other examples of principles encountered are voluntariness, the principle of last resort, and that citizens should be 'better off' than before the relocation program (Arnall 2019; Begg 2018; Cernea 1997; Hayward 2008; Tadgell, Doberstein, and Mortsch 2018).

Zooming in to articles about inequalities, social justice principles were also frequently mentioned (Johnson, Penning-Rowsell, and Parker 2007; Rulleau, Rey-Valette, and Clément 2017). A comprehensive overview of relevant social justice concepts in FRM is provided by Thaler et al. (2020, p. 107). Social justice principles can be complementary or stand in competition to each other; such as is the case with the utilitarian principle (measures should benefit society as a whole), the egalitarian principle (fair distribution between individuals) and prioritarian principle (concern for the most vulnerable). Moreover, the content and implementation of individual principles and concepts can be debatable.

All of the above-mentioned values and principles encountered in the literature are ideal types. In reality, policy arrangements often contain characteristics of multiple principles, trying to find a balance between different justifiable principles (Clément, Rey-Valette, and Rulleau 2015; Driessen and van Rijswick 2011; Kaufmann, Priest, and Leroy 2018; Keessen et al. 2016). For example, FRM policy needs to strike a balance between a utilitarian concern for the wise usage of scarce public funds, prioritarian concerns with the most vulnerable, and concerns about the impact of humans upon their environment. Procedural justice is relevant for FRM, since the interpretation and implementation of different principles of social justice or concepts of good state conduct in relocation are subject to everyday politics and power asymmetries in a given society.

\subsection{Political influence in decision-making}

In this section, we will explore further why political influence and procedural justice matter for FRM. In the evaluative FRM framework of Alexander et al. (2016), procedural justice is argued to contribute to the legitimacy of FRM, and consists of three elements: (i) there are opportunities for stakeholders to challenge decisions that have been made, (ii) stakeholders have equal access to the appeal process, and (iii) the process of resolving disputes is considered to be fair (ibid). However, this understanding of procedural justice has its limitations since it only covers controversies occurring after the decision to implement measure $\mathrm{X}$ in a location $\mathrm{Y}$ has already been taken by a governing entity. An important aspect of procedural justice occurs earlier in 
the political process: the debate about the question if exposure reducing measures are necessary at all and where/how they should be implemented.

Different community members can disagree about the social, economic and ecological costs and benefits of staying or leaving. For instance, the 'last resort principle' aims to protect people from those in power who might 'use the excuse of reducing community exposure to climate change in order to conduct forced migrations for political or economic gain' (Barnett \& Webber, 2009, p. 27 as cited in Arnall, 2019). However, it is debatable and difficult to determine whether the last resort principle applies to a potential relocation site. Are there imaginable, technically feasible alternatives available, which would allow people to stay? And if so, how much resources does a society have available for protection measures to ensure affected communities can continue living and working in the same place? Questions about staying or leaving a place tend to involve fierce, normative debates about the distribution of public funds and rights of individual citizens. Hence, we should also study which people influence FRM decision-making when such questions are settled, and how political influence is distributed among community members.

\subsection{Autonomy}

A third result from the literature review is that procedural justice in FRM should also address another value: autonomy. Disregard of autonomy and freedom of choice was featured explicitly- and implicitly in several studies documenting protests from local inhabitants against involuntary relocation or land use change programs (Bertana 2020; Tadgell, Doberstein, and Mortsch 2018). Many FRM governance arrangements show a mix fo voluntary and involuntary elements, and so the distinction between the two is often fuzzy (Arnall, 2019). With forced acquisitions, citizens might not have a choice whether they want to be compensated at all. Another example is that if all other community members do relocate, or if public services are phased-out, the relocation might be voluntary on paper, but is not experienced in that way. The right against displacement, Nine (2016) argues, should be protected since the home is constitutive for a person's autonomous agency and identity formation. Along the same line of argumentation, others defended the right of voluntary immobility and staying behind (Farbotko et al. 2020). The loss of selfdetermination and freedom of choice is a special kind of damage that cannot easily be translated in monetary terms. Just as with intangible losses such as attachment to place and psychological stress, infringement of one's autonomy cannot be compensated with utilitarian compensation frameworks. Furthermore, if people are relocated after all, quality participation in the development of relocation sites is critical, as the new place should allow the person to lead a similar kind of life as they had chosen for themselves in the old location (Nine, 2016).

Despite these examples of controversies related to loss of autonomy in the literature, the governance frameworks discussed earlier, focused primarily upon participation, communication, and lawfulness. This raises the need for a conceptual framework that includes the full scope of justice, including autonomy, while still able to provide guidance with the design- and implementation of concrete FRM-measures. In the next section, we will propose political capabilities as a concept to cover procedural justice as control over political decisionmaking and autonomy.

\section{Political capabilities}

\subsection{The Capabilities Approach}

The capability approach originated with Sen (2009) and Nussbaum (2011) and is further developed by among others Holland (2008b, 2017) and Robeyns (2017). Capabilities refer to 'a person's real opportunities to do or achieve things she values. Capabilities are conditions or states of enablement that put the things a person values within her reach "(Holland 2017, 397). Moving beyond sec resource distributions, a capabilities perspective takes into account capacities and contextual vulnerabilities to understand what real opportunities people have access to. A classic example is the limits of measuring a countries' GDP or individuals' income, to establish an understanding of whether the individual citizens of that country are able to flourish. This limitation urged Sen to develop the alternative capabilities approach for economic development policy. The capabilities approach can show differences between the needs of individuals/communities in climate adaptation and FRM. Subsequently, the capability approach can justify additional government support for more vulnerable groups. An alternative debate among capability scholars deals with so-called capability ceilings. If people harm others or the environment by employing their capabilities to the fullest, posing limits to their capabilities can be justifiable (Holland 2008a; Robeyns 2016).

A range of scholars have mentioned the capabilities approaches as suitable to deal with inequalities and climate adaptation controversies (Doorn, Gardoni, and Murphy 2018; Dryzek and Pickering 2018; Holland 2012; Jepson et al. 2017; Kronlid 2014; Schlosberg 2012; Sheller and Leon 2016; Walker 2009). Favorable characteristics of the capability approach are its ability to incorporate contextual factors and value pluralism. The open-ended nature of capabilities enables flexibility and room for democratic determination of the most valued capabilities in a specific context (Walker, 2009). Sen (2009) defended a more procedural and open-ended version of the capabilities approach, in which local citizens deliberate about what capabilities they deem valuable to support. Nussbaum (2011), on the other hand, drafted a list of universal basic capabilities that can be translated to specific contexts as a starting point for development work. For example, the United Nations Human Development Index is based upon this list. One of the basic capabilities that should be guaranteed for all humans, according to Nussbaum, are political 
capabilities. We will focus in the rest of this paper upon this specific capability, because the notion of political capability helps to address the concerns with autonomy and procedural justice that emerged from the literature review, due to its focus on human agency.

\subsection{Human Agency}

A strong asset of political capabilities specifically, is the focus on the agency of people, rather than on their vulnerability (Holland, 2017). Nussbaum described political capabilities with the sentence: 'control over one's environment' which she understands as political control over your environment. The agency aspect is also embedded in the origins of the capabilities approach. In the next section, these origins will be explained alongside Sen's notion of the 'process of choice'. After that, Hollands' (2017) translation of political capabilities to the domain of climate adaptation is discussed in more detail and slightly adapted to use it to advance procedural justice in FRM.

A central concept for Amartya Sen was freedom (Sen 2002). Sen developed a procedural account of the capabilities approach, which can be related to deliberative democratic literatures. He also stressed the importance of the 'process of choice'. Sen posed the following thought experiment to explain this notion: If you don't leave your room all day because you prefer to stay inside, that is fundamentally different then if you don't leave your room all day because there is a gunman in front of your door (Sen 2009, p. 228). This thought experiment shows that a situation's 'justness' cannot only be determined based upon the substantive outcomes and that process needs to be considered as well to characterize a situation as 'just'. This is relevant for FRM, since exactly this dimension of 'process of choice' matches with the concerns identified in the literature review about free will, voluntariness, and autonomy. Let's now turn to an explanation of the concept of political capabilities and see if it is able to address these concerns.

The first and only fleshed out paper on political capabilities in climate adaptation and water management was written by Holland (2018). She critiques mainstream initiated participatory fora and public consultation, as these do not truly advance procedural justice. Public participation has been reported to falsely legitimize expert-driven FRM and transform into lip service of government agencies (Bertana 2020); or they fail to represent all citizens equally. For Holland, an indicator of procedurally just climate adaptation would be that vulnerable populations are able to shape adaptation decisions (Holland, 2017). She focusses primarily on the empowerment of vulnerable communities. For disadvantaged groups 'having the political capability to adapt means being able to apply enough political pressure within unjust adaptation decision processes to successfully push decisions in a particular direction' (ibid., p.397).

Holland's description of political capabilities and empowerment is however still too limited. By only focusing on vulnerable communities, she neglects the opposite possibility: some actors can have too much power to shape adaptation decisions.

\subsection{Unequal political capabilities}

With the concept of political capabilities, we can analyze FRM decision-making in a specific context and include in the analysis both citizens that have too much as well as those that have too little political capabilities to shape FRM decision-making in a specific context. An example of people having 'too little' political capabilities would be marginalized communities that are subject of state-led relocation processes and hardly have the means to oppose or steer developments. On the other end of the spectrum, you can find resourceful actors such as secondhome owners and capital-rich companies that are able to secure high-value buy out sums or flood protection measures funded with public tax money. In the literature review, several examples arose where individual citizens or local action groups halted decision-making and in certain cases, it can be argued, perhaps had too much political power. An English NGO employee explained: "large floods do become political footballs [...] why did 150 homes in Somerset get all that money and attention and 4000 in the north of England didn't (Alexander et al. 2016 , p. 45). Similarly, in France, reports are made about rich coastal communities' pressuring local decision makers to choose sea defenses over managed retreat (Clément, Rey-Valette, and Rulleau 2015; Fouqueray, Trommetter, and Frascaria-Lacoste 2018). Mayors can use coastal land as electoral bait, since it helps to create employment and population growth; despite the associated risk of unsustainability and maladaptation considering long-term sea-level rise and coastal erosion (ibid).

Important to note, is that capabilities should be understood and analyzed in a contextually embedded fashion (Robeyns 2017, 2020). Especially when looking at political capabilities, we should examine existing power structures and power asymmetries to understand opportunities and restrictions for different actors. People's abilities to influence decision-making intersects with patterns of (mis)recognition and social discrimination. In the USA, several geographers describe racial patterns in buy-out locations and investments in flood protection (Hardy, Milligan, and Heynen 2017; Loughran, Elliott, and Kennedy 2019). An example of a group being overrepresented in FRM decision-making, is illustrated by the observation that the typical participants of consultations from the Dutch government are primarily highly educated and often elderly citizens that have spare time (van Buuren and Edelenbos 2008; Van der Meer 2018). In sum, the excesses on both thresholds - having too much or too little political capabilities - risk creating unjust situations.

What matters as well, is the distribution of political influence within and between groups. There are power differences and struggles between and within local communities. For instance, in response to a relocation case in Dhaka, Bangladesh, more affluent private landowners were able to write petitions and appeal in the 
supreme court claiming a violation of their rights, while lower income people from the same area were simply displaced (Nijhum 2019 p. 207, in cite Hossain, 2013, p. 374). Moreover, handing over power to 'the community' might sound laudable, but in reality, local populations are not monolithic. The issue of competing interests and values remains also at the local community level. Ideally, these kinds of dynamics are monitored in order to at least make visible which groups are systematically underrepresented from the beginning of a FRM policy process.

In order to balance people's political capabilities, a range of planning and implementation tools should be developed to mitigate possible biases and structural barriers. For example, the right regulations within a democratic state can help to create more of a level playing field for lobbying activities. Other options to be investigated are increasing avenues of contestation (Stirling 2008), transparency of the policy process, capacity building activities (Alemanno 2017), and the provision of financial resources or expertise. Which planning tools are most needed and helpful will have to be decided upon a case per case basis. Nevertheless, the first step consists of the analysis of the distribution of political capabilities in a specific FRM controversy.

Where law and regulations tend to be static, a focus on the political capabilities to influence decision making is more quickly adaptable to changing circumstances. If the context in which these tools are operationalized changes, the analysis of political capabilities can flexibly change accordingly.

\subsection{Limitations}

A limitation of the concept of political capabilities' is its inability to handle claims of ecological justice and utilitarian concerns. There are interests and values that span beyond the communities' geographic boundaries, but still should be weighed in on the adaptation decision, such as environmental integrity or resource efficiency. Another more fundamental critique is that departing from political capabilities is too anthropocentric. Politics, in its mainstream understanding, is still about how humans settle their conflicts, despite the efforts of some scholars to also include other kinds of actants (Latour 2017). The Embassy of the North Sea (Parliament of Things 2020) or Chair of the Future (Watson et al. 2020) are nice proposals, but they may not be sufficient to guarantee that ecological thinking and future generations are equally weighed in on FRM policy decisions.

Another objection could be that that the notion 'control over one's environment' reflects an overly modern disposition to control the natural environment through engineering (Bijker 2002). Recent developments in water management acknowledge the limits of human control and have shifted from full flood defense to flood risk management for that same reason (Roth and Warner 2007; Wesselink 2016). The uncertainties of climate change increasingly show that humans might have less 'control' about discharge variability and flooding than they previously hoped to be able to achieve. Climate adaptation can have two faces. On the one hand, adaptation can be about trying to control and stabilize the environment enough to continue current land use practices despite increased climate variability. On the other hand, climate adaptation can also be about fostering a more flexible, caring, and dynamic relation between humans and nature (Stirling 2020). The critique of anthropocentrism introduces an alternative take on climate adaptation and as such shows the relevance of procedural justice, since it shows there may be competing sociotechnical imaginaries for the future that need to be accounted for. Where competing visions exist, human politics will be part of FRM.

\subsection{Sufficient political control over one's environment}

To conclude, we propose that political capabilities amount to having sufficient political control over one's environment. In this way, the analysis can include both actors that have too little as well as those that have too much political influence. Furthermore, the notion of 'sufficient' control acknowledges the realization that full control is out of reach - and perhaps even undesirable due to remaining deep uncertainties in hydro-social systems. Besides, the literature review showed the relevance of the value of autonomy and this value is well reflected in notions such as freedom and human agency upon which the capability approach is based. In the next section, we develop a more specific proposal to use the concept of political capabilities in the analysis and practice of flood risk management in Europe.

\section{Application in Flood Risk Management: Room for the River}

Political capabilities can help to analyze- and possibly address inequalities in political influence in FRM. Procedural justice is not only about good government conduct in the implementation of projects; but also about the influence citizens have to propose- and alter government plans altogether. Some people have good knowledge of government operations and relevant networks to mobilize, while others feel like 'the government' is a threatening, black-boxed institution. Despite the usefulness of trying to develop substantive principles of good FRM, what matters most for application in practice (Holland, 2017), is identifying which actors are (not) able to push, prioritize, and interpret the range of values, norms, and principles that apply to FRM. Creating more of equality in terms of political influence, might help to settle disagreements about FRM in a more just manner.

Political capabilities and the distribution of political capabilities among actors can only be understood after thorough contextual analysis. A focus on Western Europe can be justified, as these states have similar legal systems due to how the irrespective representative democracies have developed over time. Zooming in further, the Dutch context has special characteristics that strongly influence discussions about justice in FRM. For example, two-third 
of the country is subject to flooding, which explains that national solidarity is evoked as a strong principle (Keessen et al. 2016). Furthermore, the areas under threat - including the country's economic center - are not necessarily poor or marginalized, which is often the case in other water justice literatures (Warner et al. 2020). With regard to the institutional setting, the Dutch Water Act is quite strong as it allows for expropriation in the name of flood defense. Water authorities are also able to enforce to tolerate [water] on land, even if this is against the wishes of the landowner (Thaler, Doorn, and Hartmann 2020). Compensation is obligatory and carefully regulated in the Netherlands; yet, if attempts to enter into a voluntary agreement fail, the authorities can move to expropriation and forced acquisition when the price of the property is settled in court (ibid). Many citizens around Zutphen will remember the households that needed to be relocated, and the impact the relocation had also in terms of loss of self-determination. The opposite dynamic shows in Austria, here, landowners have a stronger position. Subsequently, buy-out prices to use agricultural land as retention areas tend to be higher. As a consequence, this increases the costs of flood risk management for society as a whole. (Thaler, Doorn, and Hartmann 2020) At last, richer and higher-educated citizens tend to be more vocal in their protests against FRM interventions on their lands (Warner et al. 2020). All these examples show the need to study how inequalities in political capabilities are tied to the legal system and socio-economic structures in a specific context.

The Room for the River program in the Netherlands showcased multiple projects with all kinds of FRM and exposure reducing measures. At different locations, different issues with local actors having too much- or too little political capabilities were visible (Edelenbos et al. 2017). For instance, protests in the IJsseldelta used the slogan 'Bye Bye Byepass' and successfully blocked progress of the project. By mobilizing counter expertise, a coalition of farmers, environmentalist, left and right wingers pushed a different scale frame that helped to undermine the perceived necessity and suitability of the proposed FRM measure (Warner et al. 2020). A different kind of example is how at the constructed bypass at Veessen-Wapenveld case large compensation sums were negotiated for the reconstruction of farmhouses on terps. At last, in the Overdiep case, farmers were quoted to want to 'determine their own future' (idem, p. 56), reflecting the value of autonomy also at play in Room for the River controversies. Secondary literature and document analysis coupled with interviews with practitioners and citizens will lead to a richer understanding of the influence of inequalities between actors' political capabilities in the Room for the River program and the balancing of competing values in FRM. After such an empirical analysis, the concept of political capabilities can be further refined for wider application in FRM in practice.

A contextual analysis of political capabilities can help to show which actors are below or above the threshold of sufficient political control over their environment. This information and help to develop tailored mitigation measures to create more of a level playing field and take away barriers to influence FRM and climate adaptation decisions. The interviews should at least check the following elements to operationalize the concept of political capability: (a) the ability to mobilize expertise and/or counter expertise, (b) the possibility of alliances with other (more powerful) stakeholders, (c) the ability to reach media and presentation skills, (d) knowledge of government procedures and timing of decision-making processes, (e) resources: time to attend meetings and organize lobbying activities, funds to support the activities, and the relevant network to strengthen the lobbying efforts, (f) social/cultural capital and social cohesion of a community (Edelenbos et al. 2017; Holland 2017). Additionally, further research needs to address the question of how these abstract notions can be translated into planning tools, and how the interests of non-humans and future generations can be convincingly incorporated in a procedural justice approach based upon political capabilities.

\begin{tabular}{|c|c|}
\hline Steps & Researching political capabilities in FRM \\
\hline 1 & Characteristics of the hydro-social system \\
\hline 2 & $\begin{array}{l}\text { Legal- and institutional analysis to } \\
\text { understand background conditions of } \\
\text { political processes }\end{array}$ \\
\hline 3 & $\begin{array}{l}\text { Stakeholder analysis: mapping of } \\
\text { stakeholders and power analysis. } \\
\text { - } \quad \text { Alliances with other stakeholders/ } \\
\text { community members } \\
\text { - } \quad \begin{array}{l}\text { Mobilization of expertise / counter- } \\
\text { expertise }\end{array} \\
\text { - } \quad \text { Resources available (time, money, } \\
\text { networks, knowledge, cultural } \\
\text { capital/recognition) } \\
\text { - Media interaction } \\
\text { - }\end{array}$ \\
\hline 4 & $\begin{array}{l}\text { Government perspective: what is the } \\
\text { rationale behind the measure? } \\
\text { - Try to find a plurality of perspectives; } \\
\text { government is not a monolithic } \\
\text { organization. }\end{array}$ \\
\hline 5 & $\begin{array}{l}\text { Citizen X perspective: how is the project } \\
\text { perceived? And the interaction with the } \\
\text { government agency? } \\
\text { - Ask about the choice/measure presented } \\
\text { by the project, the process of the choice, } \\
\text { and possible alternatives } \\
\text { - Repeat for Citizen Y, Z, W }[\ldots . .] \\
\text { - Try to find a plurality of perspectives. }\end{array}$ \\
\hline 6 & $\begin{array}{l}\text { Identify- and cross-check opportunities to } \\
\text { level political capabilities }\end{array}$ \\
\hline
\end{tabular}

Table 1. Proposed topics to research political capabilities in the Room for the River case. 
Flood Risk Management by itself cannot take away existing socio-economic and political inequalities. However, it can help to prevent reinforcing these inequalities and perhaps create more of a level playing field in terms of political influence in FRM. In this way, we might help to avoid the scenario of a world undergoing climate change in which 'big fish devour the small fish' (Sen 2009) while deciding upon the best approach to mitigate flooding in the future.

\section{References}

1. Adams, H. (2016). "Why Populations Persist: Mobility, Place Attachment and Climate Change." Population and Environment 37(4): 429-48.

2. Adger, W.N., H.Q. Jouni Paavola, and M.J. Mace. (2006). Fairness in Adaptation to Climate Change. London, England: The MIT Press.

3. Ajibade, I., M. Sullivan, and M. Haeffner. (2020). "Why Climate Migration Is Not Managed Retreat: Six Justifications." Global Environmental Change 65(October).

4. Alemanno, A. 2017. Lobbying For Change: Find Your Voice To Create A Better Society. London: ICON.

5. Alexander, M., S. Priest, and H. Mees. (2016). "A Framework for Evaluating Flood Risk Governance." Environmental Science and Policy 64: 38-47.

6. Arnall, A. (2019). "Resettlement as Climate Change Adaptation: What Can Be Learned from State-Led Relocation in Rural Africa and Asia?" Climate and Development 11(3): 253-63.

7. Baker, C. K. S.B. Binder, A. Greer, P. Weer, and K. Gates (2018). "Integrating Community Concerns and Recommendations Into Home Buyout and Relocation Policy." Risk, Hazards and Crisis in Public Policy 9(4): 455-79.

8. Begg, C. (2018). "Power, Responsibility and Justice: A Review of Local Stakeholder Participation in European Flood Risk Management." Local Environment 23(4): 383-97.

9. Bertana, A. (2020). "The Role of Power in Community Participation: Relocation as Climate Change Adaptation in Fiji." Environment and Planning C: Politics and Space 38(5): 902-19.

10. Bijker, W. E. (2002). "The Oosterschelde Storm Surge Barrier: A Test Case for Dutch Water Technology, Management, and Politics." Technology and Culture 43(3): 569-84.

11. Boelens, R., Jaime H., Erik S., and Jeroen V.. (2016). "Hydrosocial Territories: A Political Ecology Perspective." Water International 41(1): 1-14. http://dx.doi.org/10.1080/02508060.2016.1134898.

12. Van Buuren, A., and J. Edelenbos. (2008). "Kennis En Kunde Voor Participatie: Dilemma's Voor Legitimiteit in de Participatiemaatschappij." In Burger in Uitvoering - Jaarboek 2008: 184-213. http://repub.eur.nl/pub/13398/Van Buuren.pdf.
13. Cernea, M. (1997). "The Risks and Reconstruction Model for Resettling Displaced Populations." World Development 25(10): 1569-87.

14. Clément, V., H. Rey-Valette, and B. Rulleau. (2015). "Perceptions on Equity and Responsibility in Coastal Zone Policies." Ecological Economics Vol 119: 28491.

15. Doorn, N. (2019). Water Ethics. Rowman \& Littlefield international.

16. Doorn, N., P. Gardoni, and C. Murphy. (2018). "A Multidisciplinary Definition and Evaluation of Resilience: The Role of Social Justice in Defining Resilience." Sustainable and Resilient Infrastructure 9689:1-12. http://doi.org/10.1080/23789689.2018.1428162.

17. Driessen, P.J. and H.F.M.W. van Rijswick. (2011). "Normative Aspects of Climate Adaptation Policies." Climate Law 2. http://heinonline.org/HOL/Page?handle=hein.journal s/climatla2\&id $=544 \& \operatorname{div}=32 \&$ collection $=$ journals (April 28, 2017).

18. Dryzek, J.S., and J. Pickering. (2018). The Politics of the Anthropocene. Oxford University Press.

19. Edelenbos, J., A. Van Buuren, D. Roth, and M. Winnubst. (2017). "Stakeholder Initiatives in Flood Risk Management: Exploring the Role and Impact of Bottom-up Initiatives in Three 'Room for the River' Projects in the Netherlands." Journal of Environmental Planning and Management 60(1): 47-66. http://dx.doi.org/10.1080/09640568.2016.1140025.

20. Eriksen, S., H., A. J. Nightingale, and H. Eakin. (2015). "Reframing Adaptation: The Political Nature of Climate Change Adaptation." Global Environmental Change 35: 523-33.

21. Farbotko, C., O. Dun, F. Thornton, D.E. McNamara, and C. McMichael. (2020). "Relocation Planning Must Address Voluntary Immobility." Nature Climate Change 10(8): 702-4. http://dx.doi.org/10.1038/s41558-020-0829-6

22. Fouqueray, T., M. Trommetter, and N. FrascariaLacoste. (2018). "Managed Retreat of Settlements and Infrastructures: Ecological Restoration as an Opportunity to Overcome Maladaptive Coastal Development in France." Restoration Ecology 26(5): 806-12.

23. Haasnoot, M., J. Kwadijk, J. van Alphen, D. Le Bars, B. van den Hurk, F. Diermanse, A. van der Spek, G. Oude Essink, J. Delsman, and M. Mens (2020). "Adaptation to Uncertain Sea-Level Rise; How Uncertainty in Antarctic Mass-Loss Impacts the Coastal Adaptation Strategy of the Netherlands." Environmental Research Letters 15(3).

24. Hardy, R. D., R. A. Milligan, and N. Heynen. (2017). "Racial Coastal Formation: The Environmental Injustice of Colorblind Adaptation Planning for SeaLevel Rise." Geoforum 87(October): 62-72. http://dx.doi.org/10.1016/j.geoforum.2017.10.005.

25. Hayward, B. (2008). "Nowhere Far from the Sea': Political Challenges of Coastal Adaptation to Climate Change in New Zealand." Political Science 60(1): 47-59. 
26. Heyward, C. (2017). "Ethics and Climate Adaptation." The Oxford Handbook of Environmental Ethics : 474-486.

27. Holland, B. (2008a). "Ecology and the Limits of Justice: Establishing Capability Ceilings in Nussbaum's Capabilities Approach." Journal of Human Development 9(3): 401-25.

28. - (2008b). "Justice and the Environment in Nussbaum's 'Capabilities Approach': Why Sustainable Ecological Capacity Is a MetaCapability." Political Research Quarterly 61(2): 319-32.

29. - (2012). "Ethical Adaptation to Climate Change Dignified Human Life Requires a Stable Climate System."

30. _ (2017). "Procedural Justice in Local Climate Adaptation: Political Capabilities and Transformational Change." Environmental Politics 26(3): 391-412. http://dx.doi.org/10.1080/09644016.2017.1287625.

31. Intergovernmental Panel on Climate Change (IPCC) (2014). Climate Change 2014: Impacts, Adaptation, and Vulnerability. Part A: Global and Sectoral Aspects. Contribution of Working Group II to the Fifth Assessment Report of the Intergovernmental Panel on Climate Change. eds. C.B. Field et al. Cambridge, New York: Cambridge University Press.

32. Jasanoff, S., and S. Kim. (2019). 60. Technology and Culture. Dreamscapes of Modernity: Sociotechnical Imaginaries and the Fabrication of Power Ed. by Sheila Jasanof. eds. Sheila Jasanoff and Sang-Hyun Kim. Chicago and London: The University of Chicago Press.

33. Jepson, W. J. Budds, L. Eichelberger, L. Harris, E. Norman, K. O’Reilly, A. Pearson, S. Shah, J. Shinn, C. Staddon, J. Stoler, A. Wutich, S. Young. (2017). "Advancing Human Capabilities for Water Security: A Relational Approach." Water Security 1: 46-52. http://dx.doi.org/10.1016/j.wasec.2017.07.001.

34. Johnson, C., E. Penning-Rowsell, and D. Parker. (2007). "Natural and Imposed Injustices: The Challenges in Implementing 'fair' Flood Risk Management Policy in England." Geographical Journal 173(4): 374-90.

35. Kaufmann, M., S. J. Priest, and P. Leroy. (2018). "The Undebated Issue of Justice: Silent Discourses in Dutch Flood Risk Management." Regional Environmental Change 18(2): 325-37.

36. Keessen, A.M., M. Vink, M. Wiering, D. Boezema, W. Ernst, H. Mees, S. van Broekhoven, and M. van Eerd. (2016). "Solidarity in Water Management." Ecology and Society 21(4).

37. Klijn, F., N. E. M. Asselman, A. de Kruif, P. Bloemen, and M. Haasnoot (2016). "Implementing New Flood Protection Standards: Obstacles to Adaptive Management and How to Overcome These." E3S Web of Conferences 7.

38. Kronlid, D. (2014). Climate Change Adaptation and Human Capabilities: Justice and Ethics in Research and Policy. New York: Palgrave Macmillan.

39. Latour, B. (2017). Facing Gaia - Eight Lectures on the New Climatic Regime. Cambridge: Polity.
40. Loughran, K, J. R. Elliott, and S. W. Kennedy. (2019). "Urban Ecology in the Time of Climate Change: Houston, Flooding, and the Case of Federal Buyouts." Social Currents 6(2): 121-40

41. Lynn, K. A. (2017). "Who Defines 'Whole': An Urban Political Ecology of Flood Control and Community Relocation in Houston, Texas." Journal of Political Ecology 24(1): 951-67.

42. Maier, H. R., J.H.A. Guillaume, H. van Delden, G.A. Riddell, M. Haasnoot, and J.H. Kwakkel. (2016). "An Uncertain Future, Deep Uncertainty, Scenarios, Robustness and Adaptation: How Do They Fit Together?" Environmental Modelling and Software 81:

154-64. http://dx.doi.org/10.1016/j.envsoft.2016.03.014.

43. Van der Meer, T. (2018). "De Participatie-Elite En de Participatieparadox." Stuk Rood Vlees. http://stukroodvlees.nl/de-participatie-elite-en-departicipatieparadox/ (September 24, 2018).

44. Morita, A. (2016). "Infrastructuring Amphibious Space: The Interplay of Aquatic and Terrestrial Infrastructures in the Chao Phraya Delta in Thailand." Science as Culture 25(1): 117-40.

45. Nine, C. (2016). "Water Crisis Adaptation: Defending a Strong Right Against Displacement from the Home." Res Publica 22(1): 37-52.

46. Nussbaum, M. C. (2011). "Creating Capabilities: The Human Development Approach." The Belknap Press of Harvard University Press.

47. O’Brien, K., S. Eriksen, L. P. Nygaard, and N. E. Schjolden. (2007). "Why Different Interpretations of Vulnerability Matter in Climate Change Discourses." Climate Policy 7(1): 73-88.

48. Otto, A., A. Hornberg, and A. Thieken. (2018). "Local Controversies of Flood Risk Reduction Measures in Germany. An Explorative Overview and Recent Insights." Journal of Flood Risk Management 11: S382-94.

49. Parliament of Things. (2020). "Project: The Embassy of the North Sea." https://theparliamentofthings.org/case/embassy-ofthe-north-sea/ (September 28, 2020).

50. Robeyns, I. (2016). "Having Too Much." In NOMOS LVI: Wealth. Yearbook of the American Society for Political and Legal Philosophy, eds. J Knight and M Schwartzberg. New York University Press, 1-42.

51. - (2017). Wellbeing, Freedom and Social Justice: The Capability Approach Re-Examined.

52. — . (2020). "Wellbeing, Place and Technology." Wellbeing, Space and Society 1(December): 100013. https://doi.org/10.1016/j.wss.2020.100013.

53. Roth, D., and J. Warner. (2007). "Flood Risk, Uncertainty and Changing River Protection Policy in the Netherlands: The Case of "Calmity Polders.", Tijdschrift voor Economische en Sociale Geografie 98(4): 519-25. http://doi.wiley.com/10.1111/j.14679663.2007.00419.x.

54. Rulleau, B., H. Rey-Valette, and V. Clément. (2017). "Impact of Justice and Solidarity Variables on the Acceptability of Managed Realignment." Climate Policy 17(3): 361-77. 
55. Schlosberg, D. (2007). Defining Environmental Justice: Theories,Movements and Nature. Oxford: Oxford University Press.

56. _ (2012). "Climate Justice and Capabilities: A Framework for Adaptation Policy." Ethics \& International Affairs 26(4): 445-61.

57. Schlosberg, D., L. B. Collins, and S. Niemeyer. (2017). "Adaptation Policy and Community Discourse: Risk, Vulnerability, and Just Transformation.” Environmental Politics 26(3): 41337.

58. Sen, A..(2002). "Development as Freedom." Alfred. A. Knopf. 384.

59. - (2009). The Idea of Justice. London: Penguin Books.

60. Sheller, M, and Y.M Leon. (2016). "Uneven SocioEcologies of Hispanolia: Asymmetric Capabilities for Climate Adaptation in Haiti and the Dominican Republic." Geoforum 73: 32-46.

61. Stirling, A. (2008). “'Opening up' and 'Closing down': Power, Participation, and Pluralism in the Social Appraisal of Technology." Science Technology and Human Values 33(2): 262-94.

62. - (2020). "Engineering and Sustainability: Control and Care in Unfoldings of Modernity." In Routledge Companion to Philosophy of Engineering, eds. Neelke Doorn and Diane P. Michelfelder. London: Routledge.

63. Tadgell, A., B. Doberstein, and L. Mortsch. (2018). "Principles for Climate-Related Resettlement of Informal Settlements in Less Developed Nations: A Review of Resettlement Literature and Institutional Guidelines." Climate and Development 10(2): 10215.

64. Thaler, T., N. Doorn, and T. Hartmann. (2020). "Justice of Compensation for Spatial Flood Risk Management - Comparing the Flexible Austrian and the Structured Dutch Approach." Erde 151(2-3): 104-15.

65. Walker, G. (2009). "Environmental Justice and Normative Thinking." Antipode 41(1): 203-5.

66. Warner, J., P. Werner, M. Vink, and A. Dewulf. (2020). "The Politics of Scale Framing, Ambiguity and Uncertainty: Flood Interventions in the Netherlands." In Negotiating Water Governance, ed. Christina Norman, Emma S. Cook. , 101-20.

67. Watson, Y. M. Davidson, L. Butink, J. Terlouw, and P. Logjes (2020). "De Toekomst Stoel." https://toekomststoel.nl/ (January 7, 2020).

68. Wesselink, A., J. Warner, M.A. Syed, F. Chan, D.D. Tran, H. Huq, F. Huthoff, N. Le Thuy, N. Pinter, M. van Staveren, P. Wester, and A. Zegwaard. (2016). "Trends in Flood Risk Management in Deltas around the World: Are We Going 'Soft'?" International Journal of Water Governance 4(4): 25-46. http://www.internationalwatergovernance.com//25-46.

69. Young, I. M. (1999). Justice and the Politics of Difference. 2011 edition. Princeton University Press. 